\title{
Effects of Local Wisdom-Based Practicum on Learners' Attitudes, Science Literacy, and Learning Outcome
}

\author{
Saprizal Hadisaputra* \\ Chemistry Education Study Program \\ Universitas Mataram \\ Mataram, Indonesia \\ rizal@unram.ac.id
}

Agus Abhi Purwoko

Science Education Postgraduate Program

Universitas Mataram

Mataram, Indonesia

\author{
Lalu Rudyat Telly Savalas \\ Chemistry Education Study Program \\ Universitas Mataram \\ Mataram, Indonesia
}

\author{
Muhammad Makhrus \\ Physics Education Study Program \\ Universitas Mataram \\ Mataram, Indonesia
}

\author{
Yayuk Andayani \\ Science Education Postgraduate Program \\ Universitas Mataram \\ Mataram, Indonesia
}

\begin{abstract}
The study aims to determine the effect of the implementation of local wisdom-based practicum towards students' attitudes, science literacy and learning outcomes. The research was a quasi-experiment using a Pretest-Posttest Control Group design. The population was 130 second grade high school students in Sumbawa Island, Indonesia. From those, 47 students were selected as the sample. The data related to the students' attitudes, science literacy and learning outcome were gathered from students' responses in questionnaire and multiple choices questions. Data analysis was done quantitatively. The hypothesis testing showed there is a difference between the students' attitudes, science literacy and learning outcome between control and experiment class. In general, the students in experiment class who using local wisdom based-practicum activities attained higher mean scores for every variable. The correlation test also showed a strong relation among the variables. Moreover, the attitudes and science literacy were related and implied to the improvement in learning outcome. To conclude, local wisdom-based practicum influenced the students' attitudes, literacy and learning outcome in science.
\end{abstract}

Keywords - Local wisdom; practicum, attitudes, literation skills, learning outcomes

\section{INTRODUCTION}

The aim of the science learning is to strengthen the identity values of a country, especially one with various cultural backgrounds, such as in Indonesia. There is increasing suggestion that science teaching and learning in Indonesia should accommodate the students to wisely implement the knowledge to preserve and protect the local wisdom and embrace the diversity in the country $[1,2]$. Therefore, science classroom should be integrated to the local context, by emphasizing the cultural strength and natural resources to produce excellent human resources who appreciate the potency of Indonesia [3,4]. No matter how intelligence a student in science, without respecting the local wisdom in the society she/he will merely become an ignorant scientist. As we expect the responsible one, science learning should be integrated to the local wisdom to manage the cultural values sustainability $[5,6]$.
Previous studies showed that the science learning in Indonesia are different to that practiced in western countries. To learn science by ignoring ethnoscience in Indonesia culture is irrelevant [7,8]. It is happened since science learning cannot be separated from daily practices in society. Integrating cultures, e.g. habits, traditional foods and beverages, etiquettes, native languages and traditional costume and arts is challenging and and at the same time providing opportunities in the process where the students engage in a rich environment that enable them in learning meaningfully. Conversely, the science learning will not be limited to transform the scientific concepts but also as the medium to transfer the cultural values.

Research revealed that integration of local wisdom in science learning enable students to learn in effective and conducive setting. The condition supports the students' conceptual understanding and develop excellence characters and values. Other studies found that the integration of local wisdom in science enhance the students' scientific literacy [9-12]. This is important since, in general, science literacy of Indonesian students is considered low. To enhance the quality of human resources who can globally match, the improvement in science literacy is urgently needed. The scientific thinking and ability to distinguish the information based on the science knowledge will protect Indonesia citizen toward misleading data that highly distributed by the availability of technology, internet and communication tools. Also, the students' good characters based on local wisdom, e.g. hard work, team work, religious and respect to cultural diversity should be embraced in learning process to establish their identity as Indonesian.

The preliminary studies highlighted that most of students encountered difficulties in connecting the concepts of biology, physics, chemistry, earth and space science with the local wisdom from where they live [13-15]. It is stammed from the fact that the scientific knowledge in school usually be taught separately with the local practices. On the other hand, it is known that students will learn the best way when they can integrate their experiences to the learning process. 
Therefore, it is necessary to integrate the local wisdom with the science teaching and learning in the classroom.

To achieve the goal in having a literate students and excellence in characters, improvement in the quality of science learning is needed. One method to do so is by developing a thematic module for practicum based on the local wisdom. The use of local wisdom in learning is supported by the regional rules that encourage the use of local wisdom and local genius by considering the national standard of education to transform cultural values in every educational level.

The present study focused on the development of practicum modules based on local wisdom in order to improve the students' attitudes, literacy and learning outcome in science. The thematic integrative module implemented in this study is based on the local wisdom of Sumbawa, a region in West Nusa Tenggara, Indonesia. Sumbawa has various resources of local wisdom, for instance Melala which is a tradition of using the coconut egg. The practice of Melala can be connected to the chemistry content in science learning, especially the colloid topic.

\section{METHODS}

This quasi-experiment was deliberately chosen as the method since the control group of the present study cannot fully control the variables that might influence the result of the study. The design of the quasi-experiment was PretestPosttest Control Group in which two groups were assigned with different treatment and evaluations were performed before and after the treatment. The control group followed the classical class as is used to do in the class, while the experiment class followed the local wisdom-based practicum.

The population was 130 second grade senior high school students in Sumbawa Island, Indonesia. The samples were taken by using purposive technique where 47 students were selected. Those students grouped into control and experiment classes. The data were gathered from questionnaire with 20 item responses combined with multiple choices. The tests were given twice, i.e. before (Pre-test) and after (Post-test) the treatment.

The collected data were not in form of interval. Hence, the raw data were transformed into interval by using Winsteps Program (Rasch Model). The model can be used to solve the problem in data interval by accommodating the transformation [16-18]. The transformed interval data were used in hypothesis testing after fulfilling the pre-requirement of normality and homogeneity tests.

\section{RESULTS AND DISCUSSION}

The students' attitudes manifested in their willingness to work hard. This study showed a significant difference in hard work attitudes of the students who learn with local wisdombased practicum module with those who use conventional practicum. Table 1 presents the students' attitudes in control and experiment class. The hypothesis was tested using t-test and it found $\mathrm{t}_{\text {stat }}$ equals 0.00 or less than 0.05 .
TABLE 1. RESULTS OF STUDENTS’ ATTITUDES

\begin{tabular}{|c|c|c|c|c|c|c|}
\hline \multicolumn{7}{|c|}{ Independent Samples Test } \\
\hline \multicolumn{2}{|c|}{} & $\begin{array}{c}\text { Levene's Test } \\
\text { for Equality } \\
\text { of Variances }\end{array}$ & \multicolumn{2}{c|}{ t-test for Equality of } \\
Means \\
\cline { 3 - 7 } & $\mathrm{F}$ & Sig. & $\mathrm{t}$ & $\mathrm{df}$ & $\begin{array}{c}\text { Sig. } \\
(2- \\
\text { tailed })\end{array}$ \\
\hline $\begin{array}{c}\text { Learner } \\
\text { attitudes }\end{array}$ & $\begin{array}{c}\text { Equal } \\
\text { variances } \\
\text { assumed }\end{array}$ & 4.046 & .051 & 6.196 & 43 & .000 \\
\cline { 2 - 7 } & $\begin{array}{c}\text { Equal } \\
\text { variances } \\
\text { not } \\
\text { assumed }\end{array}$ & & & 6.244 & 39.490 & .000 \\
\hline
\end{tabular}

The students' literacy in science were tested by using ttest as well. The results can be observed in Table 2 .

TABLE 2. RESULTS OF STUDENTS' SCIENCE LITERACY

\begin{tabular}{|c|c|c|c|c|c|c|}
\hline \multicolumn{7}{|c|}{ Independent Samples Test } \\
\hline & & \multicolumn{2}{|c|}{$\begin{array}{c}\text { Levene's Test } \\
\text { for Equality of } \\
\text { Variances }\end{array}$} & \multicolumn{3}{|c|}{$\begin{array}{l}\text { t-test for Equality of } \\
\text { Means }\end{array}$} \\
\hline & & $\mathrm{F}$ & Sig. & $\mathrm{t}$ & df & $\begin{array}{l}\text { Sig. } \\
(2- \\
\text { tailed } \\
)\end{array}$ \\
\hline $\begin{array}{l}\text { Scienc } \\
\mathrm{e} \\
\text { literac }\end{array}$ & $\begin{array}{c}\text { Equal } \\
\text { variances } \\
\text { assumed }\end{array}$ & 3.433 & $\begin{array}{r}.07 \\
1\end{array}$ & $\begin{array}{r}3.44 \\
7\end{array}$ & 43 & .001 \\
\hline $\mathrm{y}$ & $\begin{array}{c}\text { Equal } \\
\text { variances not } \\
\text { assumed }\end{array}$ & & & $\begin{array}{r}3.48 \\
3\end{array}$ & $\begin{array}{r}36.65 \\
0\end{array}$ & .001 \\
\hline
\end{tabular}

The third variable in the present study is learning outcome in science. Consider the summary presented in the following Table 3 .

TABLE 3. RESULTS OF STUDENTS' LEARNING OUTCOME

\begin{tabular}{|c|c|r|r|r|r|r|}
\hline \multicolumn{2}{|c|}{ Independent Samples Test } \\
\hline \multicolumn{2}{|c|}{} & $\begin{array}{c}\text { Levene's Test } \\
\text { for Equality of } \\
\text { Variances }\end{array}$ & \multicolumn{3}{|c|}{$\begin{array}{c}\text { t-test for Equality of } \\
\text { Means }\end{array}$} \\
\cline { 3 - 7 } & $\mathrm{F}$ & Sig. & $\mathrm{t}$ & $\mathrm{df}$ & $\begin{array}{c}\text { Sig. (2- } \\
\text { tailed) }\end{array}$ \\
\hline \multirow{2}{*}{$\begin{array}{c}\text { Learning } \\
\text { Outcomes }\end{array}$} & $\begin{array}{c}\text { Equal variances } \\
\text { assumed }\end{array}$ & 1.153 & .289 & 3.357 & 43 & .002 \\
\cline { 2 - 8 } & $\begin{array}{c}\text { Equal variances not } \\
\text { assumed }\end{array}$ & & & 3.365 & 42.813 & .002 \\
\hline
\end{tabular}

According to the test result in Table 2, in can be concluded that the science literacy of students in experiment and control class was significantly different. While the result in Table 3 confirmed the significant difference between the students who learn through local wisdom-based practicum module and conventional.

In addition, we can also consider the difference of every variables in the control and experiment classes. The average scores of the experiment class in each variable were higher than that of control class. See the comparison in Fig.1. 


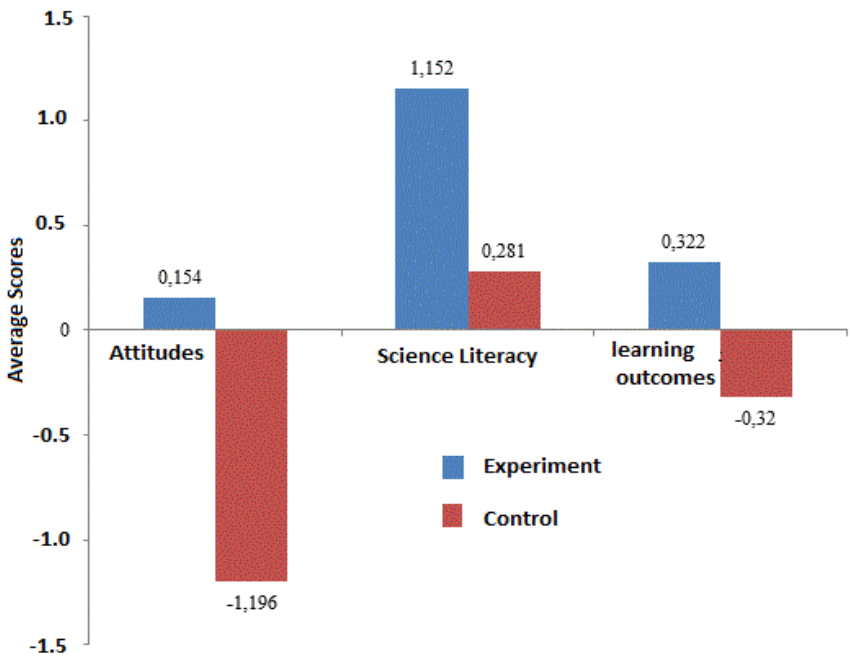

Fig.1. The comparison of students' attitudes, science literacy and learning outcome in control and experiment classes

Fig.1 indicates the averages scores of hard work attitudes of the experiment class is higher than the control $(0.154>-$ 1.96). This suggests that the implementation of local wisdom in practicum improved the students' attitudes. In term of science literacy, it was also found that students in experiment class performed better than students in control class (1.152 > 0.281 ). Hence, the literacy of students was increased due to the integration of local wisdom. In addition, the average learning outcomes of experiment class was outperformed the control class $(0.322>-0.320)$. It showed the better result due to the use of local wisdom in learning.

The local wisdom-based practicum encouraged students to be independent in learning. It increased the students' hard work attitude as they no longer wait to be told before trying their best. It also improved other characters of students since they become more details in gathering and confirming information, creative, discipline and resilience to achieve their goals. From the observation, it was found that the students in experiment class were also actively engage in the practicum activities. The findings of the present study in line with the previous studies that the local wisdom-based learning enable students to develop their confidences, creativity, hard work, literacy and learning outcome in general.

The improvement in many aspects as the result of the implementation of local wisdom was influenced by connecting students' daily experience into classroom experiment. In this study, the tradition of people in Sumbawa enhance the students' interest, motivation and participation which encourage them to follow the lesson meaningfully. The scientific knowledge they got in the classroom also enriched their understanding of the local practices they previously experienced [20-24].

Based on the test of the relation between hard work, literacy and learning outcome, it was found that there was a significant relation among these aspects. The results showed the improvement in literacy will improve the attitudes and learning outcomes. Also, the enhancement in attitudes lead to better result in literacy and learning outcome. Consider the following Table 4
TABLE 4. THE RELATION BETWEEN ATTITUDES, LITERACY AND LEARNING OUTCOMES IN SCIENCE

\begin{tabular}{|c|c|c|c|c|c|}
\hline \multicolumn{6}{|c|}{ Multiple Comparisons } \\
\hline & (I) Variable & (J) Variable & $\begin{array}{c}\text { Mean } \\
\text { Difference } \\
(\mathrm{I}-\mathrm{J})\end{array}$ & $\begin{array}{l}\text { Std. } \\
\text { Error }\end{array}$ & Sig. \\
\hline \multirow{6}{*}{$\begin{array}{l}\text { Tukey } \\
\text { HSD }\end{array}$} & \multirow{2}{*}{$\begin{array}{l}\text { Science } \\
\text { Literacy }\end{array}$} & $\begin{array}{l}\text { Learning } \\
\text { Outcomes }\end{array}$ & $.83087^{*}$ & .25258 & .005 \\
\hline & & $\begin{array}{l}\text { Attitudes Hard } \\
\text { work }\end{array}$ & $.99870^{*}$ & .25258 & .001 \\
\hline & \multirow{2}{*}{$\begin{array}{l}\text { Learning } \\
\text { Outcomes }\end{array}$} & Science Literacy & $-.83087^{*}$ & .25258 & .005 \\
\hline & & $\begin{array}{c}\text { Attitudes Hard } \\
\text { work }\end{array}$ & .16783 & .25258 & .785 \\
\hline & \multirow{2}{*}{$\begin{array}{l}\text { Attitudes } \\
\text { Hard work }\end{array}$} & Science Literacy & $-.99870^{*}$ & .25258 & .001 \\
\hline & & $\begin{array}{c}\text { Learning } \\
\text { Outcomes }\end{array}$ & -.16783 & .25258 & .785 \\
\hline
\end{tabular}

From Table 4, it can be seen that there was a significant relation between students' hard work attitudes toward the science literacy. Also, the combination of those aspects contributed to the improvement in learning outcome. Compared to other combination, the relation between hard work attitudes and science literacy provided the best result.

\section{CONCLUSION}

The results of the present study showed that science should be learned integrally with local wisdom. The integration supports the students to grasp stronger to the concept and develop a good character as supported by the wisdom on the society. The study found that the implementation of local wisdom based-practicum thematic module in science increased the students' attitudes, literacy and learning outcomes. The attitude centered in the study was hard working attitude as it was the excellence point of wisdom in the society in which this study was conducted. Also, the positive correlation between three variables in the study was found. In detail, the consistent and persistence hard work contributed to the favorably literacy and learning outcomes in science.

\section{REFERENCES}

[1] Maretta, Y. (2016). Preparing Prospective Teachers in Integrating Science and Local Wisdom through Practicing Open Inquiry. Journal of Turkish Science Education (TUSED), 13(2).

[2] Parmin, P., Sajidan, S., Ashadi, A., \& Sutikno, S. (2015). Skill of teacher candidates in integrating the concept of science with local wisdom. Jurnal Pendidikan IPA Indonesia, 4(2).

[3] Hairida, H. (2017). Using Learning Science, Environment, Technology and Society (SETS) Local Wisdom and based Colloids Teaching Material. Journal of Education, Teaching and Learning, 2(1), 84-89.

[4] Wang \& David. (2002). Science instruction with a humanistic twist: teachers' perceptionand practice in using the history of science in their classrooms. Science \& Education, 11, (2), 169-189.

[5] Khusniati, M. (2017). Local Wisdom-Based Science Learning Model through Reconstruction of Indigenous Science to Improve Student's Conservationist Character. Journal of Turkish Science Education, 14(3), 16-23.

[6] Parmin, P., Sajidan, S., Ashadi, A., Sutikno, S., \& Fibriana, F. (2017). Science integrated learning model to enhance the scientific work independence of student teacher in indigenous knowledge transformation. Jurnal Pendidikan IPA Indonesia, 6(2), 365-372.

[7] Hartini, S., Firdausi, S., Misbah, M., \& Sulaeman, N. F. (2018). The Development of Physics Teaching Materials Based on Local Wisdom to Train Saraba Kawa Character. Jurnal Pendidikan IPA Indonesia, 7(2), 130-137. 
[8] Singh, I. S., \& Chibuye, B. (2016). Effect of Ethnochemistry Practices on Secondary School Students' Attitude towards Chemistry. Journal of Education and Practice, 7(17), 44-56.

[9] Ajayi, V. O., Achor, E. E., \& Agogo, P. (2017). Use of Ethnochemistry Teaching Approach and Achievement and Retention of Senior Secondary Students in Standard Mixture Separation Techniques. Journal of the International Centre for Science, Humanities and Education Research (ICSHER), 3(1), 21-30.

[10] Ajayi, V. O., Agamber, T., \& Angura, T. (2017). Effect of Gender on Students' Interest in Standard Mixture Separation Techniques Using Ethnochemistry Teaching Approach. Sky Journal of Educational Research, 5(5), 027-033.

[11] Rahmawati, Y. (2018, February). Should We Transform? Integration Cultural Ethics And Values in Chemistry Teaching And Learning. In 1st International Conference on Education Innovation (ICEI 2017). Atlantis Press.

[12] Rahmawati, Y., Ridwan, A., Rahman, A., \& Kurniadewi, F. (2019, January). Chemistry students' identity empowerment through etnochemistry in culturally responsive transformative teaching (CRTT). In Journal of Physics: Conference Series (Vol. 1156, No. 1, p. 012032). IOP Publishing.

[13] Ramandha, M. E. P., Andayani, Y., \& Hadisaputra, S. (2018, October). An analysis of critical thinking skills among students studying chemistry using guided inquiry models. In AIP Conference Proceedings (Vol. 2021, No. 1, p. 080007). AIP Publishing.

[14] Andayani, Y., Hadisaputra, S., \& Hasnawati, H. (2018, September). Analysis of the Level of Conceptual Understanding. In Journal of Physics: Conference Series (Vol. 1095, No. 1, p. 012045). IOP Publishing.

[15] Yustiqvar, M., Gunawan, G., \& Hadisaputra, S. (2019, December). Green Chemistry Based Interactive Multimedia on Acid-Base Concept. In Journal of Physics: Conference Series (Vol. 1364, No. 1, p. 012006). IOP Publishing.

[16] Samudera, W., Wildan, W., Hadisaputra, S., \& Gunawan, G. (2019, December). Development of Chemistry Learning Intruments Based on
Reading Questiong And Answering Strategy Mixed With Creative Problem Solving. In Journal of Physics: Conference Series (Vol. 1364, No. 1, p. 012002). IOP Publishing.

[17]Chan, S. W., Ismail, Z., \& Sumintono, B. (2014). A Rasch model analysis on secondary students' statistical reasoning ability in descriptive statistics. Procedia-Social and Behavioral Sciences, 129, 133-139.

[18] Hidayat, R., Patras, Y. E., Sumardi, S., \& Yusuf, A. E. (2019, April). The Analysis on Instrument Items and Condition of Lecturer's Ethical Behavior Using Rasch Model. In 3rd Asian Education Symposium (AES 2018). Atlantis Press.

[19] Wahyuni, S. (2015). Developing Science Learning Instruments Based on Local Wisdom to Improve Student's Critical Thinking Skills. Indonesian Journal of Physics Education, 11(2), 156-161.

[20] Saefullah, A., Samanhudi, U., Nulhakim, L., Berlian, L., Rakhmawan, A., Rohimah, B., \& El Islami, R. A. Z. (2017). Efforts to improve scientific literacy of students through guided inquiry learning based on local wisdom of Baduy's society. Jurnal Penelitian dan Pembelajaran IPA, 3(2), 84-91.

[21]Alim, A., Sarwi, S., \& Subali, B. (2020). Implementation of Ethnoscience-based Guided Inquiry Learning on The Scientific Literacy and The Character of Elementary School Students. Journal of Primary Education, 139-147.

[22]Dewi, C. A., Khery, Y., \& Erna, M. (2019). An Ethnoscience Study in Chemistry Learning to Develop Scientific Literacy. Jurnal Pendidikan IPA Indonesia, 8(2), 279-287.

[23] Hartini, S., Misbah, Helda, \& Dewantara, D. (2017, August). The effectiveness of physics learning material based on South Kalimantan local wisdom. In AIP Conference Proceedings (Vol. 1868, No. 1, p. 070006). AIP Publishing.

[24] Sudarmin, R. F. K., Nuswowat, M., \& Sumarni, W. (2017). Development of Ethnoscience Approach in The Module Theme Substance Additives to Improve the Cognitive Learning Outcome and Student's entrepreneurship. In Journal of Physics: Conf. Series (Vol. 824, p. 012024). 